\title{
Temsil-Taklit İlişkisi Açısından Tasvirin Teorik Zemini -İbnü'l-Arabî'nin Eserleri Esasında-
}

\author{
Zeynep Gemuhluoğlu*
}

\section{Öz}

Tasvir meselesinin kökenindeki sûret ve temsil konusu, başlangıcından günümüze kadar bütün bir felsefe tarihinin de en temel problemidir ve bu yüzden söz konusu tartışmalar da sadece sanata özgü değildir. Tasvirin temsil ve taklit kavramları ile ilişkisi, epistemoloji-ontoloji merkezinde felsefenin, isim-sıfat tartışmaları açısından teolojinin ve elbette ahlâkın zeminini belirler. Bu makalede tasvir meselesinin felsefe açısından varlık ve oluş, teolojik açıdan da yaratma ve kurtuluş kavramlarıyla ilgisi tartışılarak temsil ve taklidin teorik zemini belirlenmeye çalışılmaktadır. Makale ayrıca meselenin İbnü'l-Arabî metinleriyle nasıl yorumlanabileceğini göstermeyi hedeflemektedir.

Anahtar Kelimeler: Tasvir, tasvir yasağı, temsil, taklit, varlık, oluş, yaradılış, kurtuluş, felsefe, sanat, teoloji, din, İslam, tasavvuf.

Doç. Dr., Marmara Üniversitesi İlahiyat Fakültesi Felsefe ve Din Bilimleri Bölümü, İstanbul/

Türkiye, zgemuhluoglu@hotmail.com, orcid.org/0000-0002-7298-8519 


\title{
The Theoretical Foundations of Depiction (Taswir) with Re- gard to The Relation Between Representation and Mimesis -According to İbn Arabî's Books-
}

\begin{abstract}
The problem of representation and mimesis which is at the roots of the issue of depiction (taswir) is from the beginning until now the most basic problem within the whole body of philosophy and, therefore, arguments in question are not limited to art only. The relation between depiction (taswir) and the concepts of representation and mimesis define the foundations of philosophy in terms of epistemology-ontology, theology with regard to 'name-designation' discussions, and, with no doubt, morality. In this article, the connection between the issue of depiction (taswir) and the concepts of "on" and "genesis" is discussed from the point of view of philosophy. In the same time, its connection to the concepts of creation and salvation are examined with regard to theology. Additionally, the author attempts at defining the theoretical foundation of representation and mimesis. Last but not least, the article aims at showing that the issue in question could be interpreted using the books of Ibn al-Arabi.
\end{abstract}

Keywords: Depiction (taswir), aniconism, representation, mimesis, taklid, existence, creation, salvation, philosophy, art, theology, religion, Islam, tasawwuf. 


\section{"Bulunmaz lâ-mekânîdir bilinmez bî-nişânîdir Hemin ancak sana kuldur senin ehl-i iyâlindir” \\ Niyâzî-i Misrî}

\section{Giriş}

\section{Tasvir Meselesinin İki Yüzü: "Varlık ve Oluş" ve/veya "Yaratılış ve Kurtuluş"}

“..Yine ağırlayan, ağırlanan ve neşe hareminin yakınları olan dostlar (Allah onların hâtırasını yüceltsin) şöyle rivâyet ettiler ki : Zamanın kraliçesi, dünyanın hanımı ve sultanın eşi olan Gürcü Hatun (Allah rahmet eylesin) hanedanın muhiplerinden ve has müridlerindendi. Daima Mevlânâ'nın verdiği şevkin ateşi içinde yanıyordu. Tesadüfen Kayseri'ye gitmek istedi. Sultan onu reddedemezdi, çünkü o kadın, seçkin ve verdiği karardan dönmeyen bir kadındı. Fakat Gürcü Hatun, Mevlânâ Hazretlerinin ayrılı̆̆ı ateşinin yüküne tahammül edemezdi. O zaman, resim yapmada ikinci bir Mani olan bir ressam vardı. Kendi sanatı hakkında "Mani, bizim sanatımız karşısında aciz kalır." derdi. Buna Aynü'd-devle-i Rûmî derlerdi. Sultan, Mevlânâ'nın resmini bir kâğılda çizmesi için ona hediyeler verdi. Yollarda Gürcü Hatun'a can yoldaşı olması için resmin son derece güzel yapılmasının icab ettiğini söyledi. Sonra Aynü'd-devle, birkaç eminle beraber bu meseleyi bildirmek üzere Mevlânâ hazretlerine geldi. Baş koyup uzakta, ayakta durdu.

Aynü'd-devle daha ağzını açmadan Mevlânâ, "Yapabilirsen ne âlâ" dedi. Ressam birkaç tabaka kağıd-ı mehzenî getirerek kalemi eline aldı ve Mevlânâ 'ya döndü. Mevlânâ ayakta duruyordu. Ressam, bir defa bakıp yüzünü çizmekle meşgul oldu. Bir yaprak kâğ tekrar baktı. Fakat Mevlânâ'nın önce görmüş olduğu şekli değişmişti. Başka bir kâğıt üzerine bir resim daha yaptı. Çehresini tamamladıktan sonra şeklin yine başka türlü olduğunu gördü. Bütün üzerine yirmi tabakaya türlü türlü resimler çizdi, fakat her baklşında resmin başka bir şekle büründügünü gördü. Hayrette kald, nârâ atıp kendisinden geçti ve kalemleri kırıp âcizler gibi yerlere kapandl. Bu sırada Mevlânâ Hazretleri şu gazele başladı:

Ah ben nasıl da renksiz ve nişansızım (bî-nişân)

Ben kendimi olduğum gibi görebilsem.

Sirlarin ortaya koy diyorsun.

Fakat benim bulunduğum yerde yer yok." ${ }^{1}$

1 Ahmed Eflâki, Ariflerin Menkıbeleri, terc. Tahsin Yazıc1, İstanbul, Remzi Kitabevi, 1986. Alıntının sonundaki gazelin tercümesinde metnin aslını esas alarak değişiklik yaptık. Gazelin aslına şu adresten ulaşılabilir https://ganjoor.net/moulavi/shams/ghazalsh/sh1759/ 
Eflâkî Ahmed Dede'nin Menâkıbü'l-Ârifin'inden okuduğumuz bu rivâyet, modern öncesi İslam düşüncesi tarihinde görsel tasvire dair önemli örneklerden biridir ve konuya ilişkin bütün tartışmalarla ilgilidir. Rivâyet ayrıca sûret ve hakikat ilişkisini Grek düşüncesi zemininde okuma alışkanlığg için de şaşırtıcıdır. ${ }^{2}$ Bilindiği gibi Symposion diyaloğunda Alkibiades -ki diyaloglarda karşımıza ç1kan en belirgin "filozof" tipidir- bir sophos olan Sokrates'in hakikî-aléthes- sûretini - eikon- yapacağını söyler. Görünürde çirkinliğiyle ünlü olan Sokrates'in "asıl” yüzünün bir tasviridir bu. Ona göre, adalet, iyilik, doğruluk ve güzelliğin mazharı olan bu yüzün "aslı", dışı çirkin ama açılınca içinden tanrı heykeli çıkan bir Silen heykelciği gibi ancak üstteki kısım açıldıktan sonra görülebilir. Elbette heykelciğin dışına değil, Alkibiades gibi içine bakabilenlerin göreceği şekilde. ${ }^{3}$ Bu sahne, Platon'un hakikati -alétheia- anlama ve açılama biçimiyle tamamen örtüşür. "Saklı olanın açılması" olarak hakikat, esasen saklı değil doxa sahnesinde yani bir anlamda sadece duyusal alanda görülenlere/ görülenlerle bakanlar için gizlidir. Ancak aslı görebilen -ki bu ancak noétik yani aklî bir temâşâdırAlkibiades için "açık"tır ve tasvir edilebilir. ${ }^{4}$ Burada adalet, iyilik, güzellik gibi "asıl" olanların tek tek Platon fikriyatındaki "eidos" ${ }^{5}$ a tekabül ettiğine de dikkat etmek gerekir.

Eflâkî Ahmed Dede'nin rivâyetini bu şekilde açıklama imkânımızın olmamas1, en temelde felsefe ve tasavvuf açısından "hakikat" konusundaki farktan ileri gelmektedir. Zira sûfîler hakikati "bir sahnedeki açıklık" ve onun seyredilmesi -theoria- olarak değil "bir perdede açılan ve yine bir perdede örtünen" olarak anlar ve anlatırlar. Daha sonra açılayacağımız gibi, perdede açılan, "asıl" yerine

2 Sûret konusunun Grek zemininde okunması alışkanlığı, modern çalışmaların kelimeyi Grekçe “eidos” un karşılığı olarak görmelerinden kaynaklanmaktadır. Bu tesbit, büyük ölçüde İslam Felsefesi literatürü için geçerlidir. Bu soruna daha sonra dikkat çekilecektir. Bu çalışmada tasvir meselesi ve kökenindeki sûret konusu, -İslam Felsefesi olarak adlandırılan alan kendisini zaten Grek zeminine bağladığı için- Grek düşüncesine paralel olarak ele al1nacaktır.

3 Eflatun, Şölen, çev. Azra Erhat-Selahattin Eyüboğlu, İstanbul, Remzi Kitabevi, 1958, 215b. Bu bölümün yorumu için bkz. Oğuz Haşlokoğlu, Platon Düşüncesinde Techné, İstanbul, Sentez Yayınları, 2016, s. 123.

4 Bu "temâşânın" özellikle Symposion diyaloğu esas alındığında arzu, aşk ve tekillik (singularity) ile ilişkisi vardır. Ancak Platon'un Politea'da kurduğu filozof tipi ile de ilişkisi düşünülmelidir. Orada Platon filozoflardan "anayasa ressamı" -zografos politeion- olarak söz eder ve onların yaptıkları "meşru" benzetmeler ve tasvirler için "soylu yalan" zemininde bir açıklama sunar. Bkz. Danielle S. Allen, Why Plato Wrote, Blackwell Publishing Ltd., 2013, s. 44.

5 Eidos: idea, sûret -ancak duyusal anlamda yani “eikon" anlamında sûret değil- 
geçemez. ${ }^{6}$ Bu meyanda "keşfü'l-mahcûb", alétheia değildir. Bu iki örnekten birinin görsel diğerinin sözel tasviri mesele edinmesi, sonucu değiştirmez. Sonraları ve özellikle günümüzde ortaya çıkan problem, büyük ölçüde "hakikat"in Grek düşüncesine bağlı olarak okunması ve sûret konusunun özellikle de Aristoteles'e nisbetle ele alınmasından kaynaklanmaktadır. Zira sûret/eidos'un Aristotelesçi "form/biçim" ile olan ilgisi, Aristoteles'in kastını aşacak şekilde zamanla kelimenin "duyusal olan", "dış görünüş" anlamının yaygınlık kazanmasıyla sonuçlanmış gibidir. ${ }^{7}$ Bilhassa günümüzde kelimenin etrafında oluşan karmaşa, tasvir meselesini olduğu kadar mesela sûfî metinlerin sıç̧a müracaat ettiği "Allah Âdem -aleyhisselam-i kendi sûretinde yarattı” hadis-i şerifini anlamayı da hayli zorlaştırmıştır.

Eflâkî Ahmed Dede'nin rivâyeti, aslında muhtemelen öncelikle tasvir meselesinden ziyade bu hadis-i şerifle, "insan-1 kâmil" düşüncesiyle ve "yaratmanın sürekliliğị” ile ilgilidir. Rivâyetin muhtemel yorumlarına geçmeden önce şimdilik tasvir meselesini, teolojiyle de ilişkisini kuracak şekilde teorik ve kavramsal olarak açmaya çalışacağız. Zira tasvir, kökeninde sûret ve hakikat ilişkisi kadar temsil ve taklit ilişkisine de bağlıdır; temsil ve taklit ilişkisi ise bir taraftan "varlık - to on- ve oluş - genesis- " diğer taraftan "yaratılış ve kurtuluş" problemine.

Burada, tasvir meselesine bağlı olarak tartışılan yasak konusunun da dinî geleneklerde öncelikle "ilahî olanın tasviri”ne ilişkin olduğunu hatırlatmakta fayda vardır ${ }^{8}$, çünkü genel anlamda tasvir konusu, esasen ilahi olanla olmayana ilişkin

6 Bu konuda Hz. Mevlânâ'nın Mesnevî’sindeki “üç şehzâde kıssası” ve yorumlarına müracaat edilebilir. Nitekim "mânâ"ya kapılan ilk şehzâde, tenzihte kalır ve hakikate ulaşamaz: "Ma'şukun sûreti ondan gizlide oldu. Gitti, ma'şukun ma'nâsı ile çift oldu/ Dedi: “Onun libâsı şa'rden ve şüşter'den olsa bile, ona i’tinâk hicâbsız daha hoştur." ("Şâr ve şüşter”: bir çeşit elbise, “i’tinâk”: boynuna sarılma) Bkz. Mevlânâ Celâddin Rûmî, Mesnevî-i Şerif Şerhi, trc. ve şerh Ahmed Avni Konuk, haz. Selçuk Eraydın, Mehmet Demirci, Mustafa Tahralı, Sâfi Arpaguş, Necdet Tosun, İstanbul, 2008, c. 13 (6), beyitler: 4637-4638.

7 Sûret kelimesinin gelenekte bu anlamda kullanıldığı da vâkidir zira sûret her zaman duyusal olanla ilişkilidir. Ancak yine de kategorik bir karşıtlık oluşturacak şekilde sadece bu anlama hasredilmesi başka bir durumdur.

8 Bu konuda Budist ve Hristiyan Geleneklerinde ortaya çıkan iki anlatı ile örnek verebiliriz. Söz konusu geleneklerde tasvir konusunda pek çok farklı açıklamalar olduğu ve bu açıklamalar etrafında ciddi bir literatür olduğu muhakkaktır. Ancak en çok müracaat edilen anlatılara yer vererek bu anlatılar çerçevesinde tasvir konusunun teoloji ile olan kesişme alanlarına işaret edilebilir:

"Geleneğe göre Tathâgata, kendi tasvirini sonraki nesillere miras bırakmıştır. Divyâvaddâna’ya göre Kral Rudyana veya Udayana, Kutsal Kişi’ye onun portresini yapmaları için 
sınırın açıklanmasına dairdir ve söz konusu "yasak", bu açıdan anlamlıdır. ${ }^{9}$ İlahi olan ve olmayan ayrımı, ilahi olmayanın yani âlemin ilahi olanla ilişkisini açıklar yani yaratılışı. Öte yandan yaratılışla ortaya çıkanın yine ilahi olanla irtibatının kurulması, yaratılışa zıt bir hareketi zorunlu kılar, yani kurtuluşu. Teolojik bir mesele olan "ilahi olan" ve "ilahi olmayan" ayrımı da esasen felsefenin, "varlık ve oluş" ayrımına paralel olarak düşünülebilir. Bu problemde tasvir, öncelikle oluşun varlıkla olan ilişkisinin teorideki ve fikriyattaki dilsel zeminine dair bir meseledir. Batı fikriyatında mesele, mitostan sonra felsefenin nasıl kurulduğunu da içerecek bir bakışı zorunlu kılar. Nitekim "felsefe", oluşu esas alan Herakleitos'a karşılık oluşu tamamen dışlayarak varlık nazariyatı sunan Permanides'in yolundan giden ancak oluşu varlık zemininde açıklamaya çalışan Platon ve Aristoteles ile kurulur.

Platon ve Aristoteles, Permanides'in "varlık"1nı esas almalarına rağmen fikriyatlarını oluşu da açıklayacak şekilde genişletirler. Platon'un, varlık -to on- ve oluşu - genesis- açıklamak için eidos'u felsefe yapmanın esasına yerleştirmesi, Aristoteles'in ise dilden metafiziğe geçişte cevher -ousia- bağlamında Platon'dan farklı bir şekilde de olsa eidos'u esas alması ile ortaya çıkan sûret ve temsil meselesi, başlangıcından günümüze kadar bütün bir felsefe tarihinin en temel problemidir. Tam da bu yüzden tasvir ve tasvir yasağına ilişkin konu sadece sanata özgü değildir. Tasvirin temsil ve taklit kavramları ile ilişkisi, epistemolo-

ressamlar göndermiş, ancak ressamlar Buda'nın misalini boş yere almaya çalışırken Buda onlara manevi tembelliklerinin bu işi yapmalarına engel olduğunu söylemiş ve elbisesini getirerek Kendi misalini onun üzerine yansıtmıştır. Bir başka Budist hikâyeye göre Tathâgata'nın bir şakirdi, boş yere onun portresini çizmeye çalışmış, doğru oranları yakalayamamış, her ölçü küçük çıkmış, sonunda Buda, ona yere yansıyan gölgesinin dış çizgisini çizmeyi emretmiştir.” Bkz. Titus Burckhardt, Doğuda ve Batıda Kutsal Sanat, çev. Tahir Uluç, İstanbul, İnsan Yayınları 2017, s. 178, 179. Buda tasvirlerine ilişkin diğer rivayetler için bkz. Ananda K. Coomaraswamy, "The Origin of the Buddha Image", The Art Bulletin, Vol. 9, No. 4, Jun., 1927, s.327-328.

Hristiyanlığa ait anlatı, daha çeşitlidir ama bu rivâyetler kendi içlerinde Budist gelenekle bir açıdan yani "insan eli değmeden mucizevî bir şekilde yapılmış" (acheiropoietos) olmalarında birleşirler. VI. yüzyıldan gelen Mandylion öyküsüne ilk kez Evagrius'un Historia Ecclesiaslica'sında rastlanır ve İsa'nın Urfa kralı Abgar'a yolladığı ve insan eliyle yapılmayan bir tasvirden söz edilir. Başka kaynaklarda karşılaşılan rivayetler de ressam Hannan'ın çizdiği portreyi Urfa'ya getirdiğini söyler. Rivayette, kalabalığın arasında resmi çizmeye çalışan ve İsa'nın güzelliğinden ve yüceliğinden çaresiz kalan ressamı İsa yanına çağırır ve örtüye yüzüne sürer, kumaşta sûreti belirir. Bu konuda bkz. Konuyla ilgili metinler ve farklı rivayetler için bkz. Marc Guscin, The Image of Edessa, Leiden-Boston, Brill Yayınları,2009, s.. 141-164.

9 İslam düşüncesi tarihinde tasvir meselesinin bu ayrımla ilgili tartışıldığı söylenemez. 
ji-ontoloji merkezinde felsefenin, isim-sıfat tartışmaları açısından teolojinin ve elbette ahlâkın zeminini belirler. Modern dönemde bu alanlar görece olarak birbirinden ayrılmış oldukları için tartışmalar kendi içlerine kapanmış ancak tam da bu yüzden mesele, içinden çıkılmaz şekilde karmaşıklaşmıştır.

İslam düşüncesi içinde görsel tasvir konusu, insan sanatına ilişkin olarak bu konuda bir yasak olup olmadığına ilişkin fikhî bir mesele olarak görülmüş, tesbit edebildiğimiz kadarıyla İslam felsefesi içinde ${ }^{10}$ tartışılmamıştır. İslam felsefesi literatüründe tasvir konusu genel anlamıyla Aristotelesçi veya Yeni-Platoncu madde-sûret ilişkisi açısından değerlendirilmiş ancak sanat konusunda Aristotelesçi Poetika esas alındığı için mesele sadece mantık içinde ve şiir ve hatâbe -retorik- açısından incelenmiştir. ${ }^{11}$ İbnü'l-Arabî’nin konuya ilişkin açıklamaları ise görsel tasvir konusunu genel tasvir problemine bağlayacak şekilde sadece fikhî açıdan veya filozoflarda olduğu gibi mantık ve şiir açısından değil varlık-oluş, temsil-taklit ve ahlâkî sonuçları açısından da açıklık getirebilmektedir.

\section{Sûret ve Tasvir}

Arapça "savvara" fiilinin masdarı olan tasvir kelimesi, "sûretlendirme" anlamına gelir ve daha ilk adımda "sûret" kelimesinden ne anladığımızı açıklamak zorluğuyla karşı karşıya kalırız. Sûreti “imge”nin karşılığ1 olarak düşünmenin işimizi kolaylaştırmayacağ 1 ve meseleleri çözmeyeceği yukarıdaki tartışmalardan sonra açığa çıkmıştır. Bu konudaki zorluk, işaret ettiğimiz gibi, büyük ölçüde İslam felsefesi literatüründe sûret kelimesinin Grekçe “eidos”un karş1lı̆̆ olarak anlaşılmasından ancak felsefe dışında da çoğunlukla bununla uyuşmayan anlamlarda kullanılmasından kaynaklanıyor gibidir. Uyuşmazlık özellikle de kelimenin sadece eidos'a değil bazen eikon'a bazen de eidolon'a tekabül edecek şekilde anlaşılmasıyla ilgilidir. Platon düşüncesinde eikon, oluş - genesis- itibariyle varlıkların, hakikatleri olan eidê'nin (eidos'un çoğulu) birer mimeton'u yani taklidi iken mesela bir ressamın bu eşyayı resmetmesi sonucunda ortaya çıkan imge ise eidolon olarak bir mimetes yani taklittir. ${ }^{12}$ Arapçaya "sûret" olarak çevrilen eidos

10 Burada kastedilen, özellikle Fârâbî, İbn Sînâ ve İbn Rüşd'dür. İşrâkî felsefe söz konusu olduğunda farklı bir durum söz konusu olabilir.

11 Bu konuda geniş bilgi için bkz. Salim Kemal, The Poetics of Alfarabi and Avicenna, Leiden-New York- Kobenhavn-Köln, Brill Yayınları 1991; Ismail M. Dahiyat, Avicenna's Commentary on the Poetics of Aristotle, Leiden, Brill, 1974. Ayrica bkz. Zeynep Gemuhluoğlu, "Metaforların Kognitif İçeriklerinin Felsefe ve Şiir Dili Açısından İncelenmesi, - Fârabi, İbn Sina ve İbn Rüşd Örnekleri-”, M. Ü. Illahiyat Fakültesi Dergisi, 34 (2008/1)

12 Platon diyaloglarında bu kavramların ilişkilerine dair bkz. Oğuz Haşlokoğlu, a.g.e. ayrıca bkz. Poul Ricoeur, Hafiza, Tarih, Unutuş, çev. M. Emin Özcan, İstanbul, Metis Yayınları 2012. 
ise Platon ve Aristoteles düşünceleri arasındaki temel farkın zeminidir. Platon, "eidos"u Aristoteles'de olduğu gibi “morphe/biçim” olarak düşünmez, eidos, daha ziyade varlığın -to on-, cevher -ousia- itibariyle ve noesis (akletme/nazar) vasitasiyla seyredilen vecheleridir.

Ontolojisi, "to de ti"13 üzerine kurulu olan Aristoteles'de ise mesele, "madde-sûret" (hyle-morphe) ilişkisi üzerinden ele alınır. Bu yüzden eidos yani sûret, bir şeyi o şey yapan, ona bireysellik kazandıran temeldir. Aristoteles'in sûret anlayışı, sanat tarihi incelemelerinde modern dönemlerde de devam eden "biçim” meselesinin kökeni olabilir. Nitekim biçimin bir temsil olmasına karşılık içeriğin oluşa dair mimetik bir fiil olması, mimesis fiilinde "ergon olarak eseri yani temsili" değil de sanatçıyı esas almayı gerektirir. Oysa bu ayrımda sanatçı değil eser yani temsil ön plandadır ve hatta taklitle temsil arasındaki ayrım bulanıklaşmaktadır. ${ }^{14}$

Konuyu açmaya çalışırsak kökende Aristoteles'in Poetika'da yaptığı mimesis açıklamasını buluruz. ${ }^{15} \mathrm{Bu}$ açıklamada tragedya üzerinden konuşan Aristoteles, mimesisin bir şeyin veya kişinin değil bir fiilin taklidi olduğunu söyler. Yani mimesisin nihai sonucu, bir fillin taklidi olarak olay-örgüsüdür -muthos-. $\mathrm{Bu}$ esasta sanatçı yani oyuncu, bir karakterin -ethos- temsilidir. Karakter ise tragedyanın asli unsuru değildir. Bu sebeple tragedyanın veya genel anlamda tiyatronun asli bir bileşeni değildir. Bu açıklama, aynı zamanda oyuncu olmasa bile eserin kendi başına bir şey olmasını temin eder. Yani biz sanatçının fiilini -"yazar" olarak sanatçı değil, oyunu fiilî hale getiren sanatçı olarak "oyuncu"esas almadan eserden yola çıkabiliriz ve eserin asılla ilişkisini fiil taklidi üzerinden kurabiliriz.

Hristiyan teolojisindeki imge tartışmalarının kısmen Platon'un terimlerini esas almakla beraber ${ }^{16}$ "sûret"i Aristotelesçi anlamında "biçim" olarak anlamala-

13 "Şurada olan" anlamında somut varolan.

14 Yukarıdaki anlatılarla ilişki kurarsak, İsa'nın yahut Buda'nın resmini yapan ressamı örneğinde mimesis fiilini, ressamın önündeki "kişı”'yi çizim yaptıkları kağıtta, zeminde taklit etmeleri açısından anladığımızda mimesisin temsilden bir farkı kalmamaktadır. Rivayetlerde karşımıza çıkan mimesis fiilinin daha sonra Batı düşüncesindeki genel-geçer anlamında "temsil" ile eşitlendiğini gösterir, bu açıdan eser ve "sûret" konusunda Aristotelesçi zeminde ortaklaştıklarını da.

15 Aristoteles, Poetika, çev. Nazile Kalaycı, Ankara, Pharmakon Yayınları, 2012, 1148a. Ayrıca bkz. Haşlaoğlu, a.g.e., s.131.

16 Bizanslılar "eikon" kelimesini kendi kutsal tasvirleri için "eidolon" terimini Hristiyan kutsalının zıddı olan pagan kültlerin putlarını ifade etmek için kullanmışlardır. Bu konuda bkz. Turan Kaçar, "İmgenin Transformasyonu: Bizans Dünyasında İkona Tartışmaları”, Eskiyeni, 2008, sayı 2, sf. 69. Bu ayrımdaki kavramlar belli ki Platon'dan alınmış ancak anlam çerçevesi değişmiştir 


\section{r1, meselenin esas düğüm noktalarından biridir. Hristiyan geleneğindeki ikonların Platon'un açıklamalarındaki "aslına uygun" tasvirle, "iz" -tupon- üzerinden de ilişkilendiğini söyleyebiliriz. ${ }^{17}$ Ancak Platon düşüncesinin görsel tasvir konusun- da bu tür bir açıklığa sahip olup olmadığı tartışmalıdır ve ayrıca incelenmelidir}

17 Burada Hristiyan teolojisinin tamamı kastedilmemektedir. Konuya birkaç önemli örnekle işaret edilebilir. Yukarıda - dipnot 8- alıntıladığımız anlatılarla da ilişkili olarak geliştirilen açıklamalarda tasvirlerin bir ve iz veya yansıma olması, özellikle de "ilahi olanın" tasviri söz konusu olduğunda, tasvirde ortaya çıkana dair bir çeşit meşruluk da temin eder gibidir. Bizans ikona-savunuculuğunun öncüsü olan Şamlı Yahya'da bu açıklama esas alınırken aynı zamanda bizzat "ezeli, ebedi ve görünmez olanın bedenlenmesi olarak İsa" anlayışına da referans yapılır; yani ezelî, ebedî ve görünmez olan Tanrı, İsa'nın bedeninde duyusal bir forma -biçime- girmiştir. İkona da benzer şekilde bu forma girmiş olan Kutsal'ın doğal izi olarak ortaya çıkmıştır. Bu konuda bkz. Guskin, a.g.e., s. 151-154; ayrıca bkz. Margaret Stokes, The Hiitory of Christian Art in the Middle Ages, London, 1891, s. 397.

Aquinolu Aziz Thomas'ın açıklaması ise iz ve imago arasındaki farklılığa dayanır. İmago, ölümden sonra yüzden alınan bir kalıp yani ölü maskesidir. Thomas, izin "nedenin etkisiyle oluşan sonucun türsel benzeşimden" farkını açıklayarak izin, canlılara özgü hareketlerin sonucu olduğunu söyler. Bu konuda bkz. Bu konuda bkz. St. Thomas Aquinas, The Summa Theologica, Benziger Bros. edition, translated by Fathers of the English Dominican Province, 1947, s. 1055, 1061-1063.

Ayrıca onun izden farklı olarak düşündüğü türsel benzeşim ise muhtemelen Aristotelesçi sûret anlayışının sonuçları ile ilgilidir. Aquinas burada izi hareketin doğal sonucu olarak açıklamaktadır. Bu düşüncenin sonucu olarak ilk ikonların, bir ressamın benzeşim üzerinden tasviri değil tıpk1 doğadaki harekete bağlı tabii bir oluş gibi açıklanmasını mümkün kılmaktadır.

Bu açıklama, Hristiyan tarihindeki İsa ikonalarını da bu ilk "iz"lerin taklidi olarak anlamayı mümkün kılmaktadır. Yani mimesis fiili, ressama ait bir fiili değil, zaten esas olan biçimsel bir sûretin "temsil" edilmesi anlamındadır. Ancak özellikle Rönesans'la başlayan merkezi yahut geometrik perspektifle ilgili tartışmalar için bu açıklama yeterli olmadığında bu defa tasvirin tekniğine değil ikonaların bizzat biçimine ilişkin savunular da geliştirilmeye çalışılır. Nikolaus Cusanus'un “De Visione Dei” (Tanrı'nın Bakışı Üzerine)'si bu konuda eşsiz bir örnektir ve sonraki din-dışı resim geleneğine hiç tesir edememiş olsa da biçimsel olarak bir ikona temellendirmesinin nasıl yapılabileceğine dair önemli ipuçları verir. Cusanus'un meselesi, Aquinas'tan farklıdır; Cusanus, insan bakışının merkeze alındığı bir gerçeklik anlayışını reddetmeye çalışırken, ikonların Tanrısal bir bakışı örneklediğini tasvirde ortaya çıkan üzerinden temellendirmeye çalışmaktadır. Ancak yine o da sonraki ikonları, ilk ikonlara yani "iz olan asıllara" giderek düşünür ve meseleyi "temsil”e bağlar. Bu konuda bkz. Hans Belting, Floransa ve Bağdat, Doğu'da ve Batı'da Bakışın Tarihi, çev. Zehra Aksu Yılmazer, İstanbul, K.Ü.Y. 2012, s. 225-228.

Yukarıdaki açıklamalar, insan eliyle ve fiiliyle "temsil edilemez" olanın ancak doğa yoluyla mümkün olduğunu, insan fiilinin, sanatının ise ancak bunu taklit ederek temsil edebileceğini öngörür. Daha önce alıntıladığımız Buda'ya ilişkin ikinci rivayet kısmen farklıdır. Fakat gölgenin dış çizgisi üzerinden yine doğal olana bağlanır. O halde rivayetler, öncelikle "ilâhî olanın temsili" ve "sûret nedir" sorusunun cevabı ile ilgilidirler. 
zira onun ressam ve şairlere olan tavrı, özellikle Politeia diyaloğu söz konusu olduğunda, çok iyi bilindiği gibi, olumsuzdur.

Benzer bir durum İslam düşüncesi söz konusu olduğunda özellikle günümüz için geçerlidir. Zira ister Yeni-Platonculuğun Aristotelesçi zemini üzerinde temellenen Fârâbî, İbn Sînâ felsefelerini isterse bütünüyle Aristotelesçi olan İbn Rüşd felsefesini esas alalım, sûret, form -biçim- anlamında düşünülmektedir. ${ }^{18}$ Oysa hadis-i şeriflerde ve sûfîlerin yazılarında karşılaştığımız "sûret" kelimesini bu şekilde anlamamızı gerektirecek meşru bir açıklama söz konusu değildir. Bu konu halen kapsamlı bir araştırmaya muhtaçtır. Konuya bir nebze yaklaşabilmek için Esmâ-i Hüsnâ'dan "el-Musavvir" ismine ve bu ismin "el-Bedî”, "el-Hâlık", "el-Bâri” ve "es-Sâni” isimleriyle olan ilişkisine dair yorumlara müracaat edilmelidir. Konunun bu minvalde incelenmesi, "tasvir yasağı" olarak bilinen meseleye daha doğru bir şekilde yaklaşmamızı da mümkün k1lacaktır.

\section{Temsil ve Taklit}

$\mathrm{Bu}$ noktada tasvir, temsil ve taklit kavramlarının teorik zeminine yönelebiliriz. ${ }^{19}$ Öncelikle bugünkü kullanımda temsil ve tasvirin s1k sık birbirine karıştırıldığını hatta bazen bu üçünün birbirine karıştırıldığını görmekteyiz. Problem, yine büyük ölçüde hem geçmişte hem de günümüzde tercümeler üzerinden düşünmemizden kaynaklanmaktadır. Özellikle temsil kelimesi hem misâl -örnek- hem de representation ${ }^{20}$-yerine geçme, ikâme- anlamında, ikinci anlamda da tasvir karşılığında sıkça kullanılmaktadır. Oysa bu kelimeler daha çok Latin ve Avrupa dilleri kökeninde şimdiki zamana ilişkin bir "mevcudiyet"le ilgilidir, bu yüzden de "bulunuş" anlamında hazret, keynûnet ve mevcudiyet" kelimeleriyle düşünülmelidir. Ayrıca reprentation'a ilişkin tartışmaların, ister sanat isterse siyaset bağlamında, esasen ontolojiye dair meselelere bağlandığına da dikkat

18 İbn Sînâ'nın sûret anlayışı ile ilgili geniş bilgi için bkz. Halil İbrahim Üçer, İbn Sina Felsefesinde Suret, Cevher ve Varlık, İstanbul, Klasik Yay, 2017.

19 Burada "teori" kelimesini "kuram" anlamında kullanmıyoruz

20 "Representaion", daha çok bir şeyi o şeyin yokluğunda ikame etme, o yokluğu giderme girişimidir. Bu içeriğiyle temsil kavramı, daha çok Paul Ricoeur'un önerdiği "representance" kelimesinin Türkçe'deki bir karşılığı olarak düşünülebilir. Ricoeur, bu kelime ile hem "tasvir"i hem de “temsil”'i kasteder. Politik ve estetik alanların kesişim noktasında bu kavram bir şeyi o şeyin yokluğunda, onun yerine geçerek ona vekâlet ederek temsil etmek anlamına gelir. Temsil ilişkisinde en çok tartışılan konu bu yüzden temsil edilenin, bir "yokluk" veya "eksiklik" olarak belirmesi, temsilin de, doğrudan bu yokluğu kapatan, bu eksikliği gideren bir ilişki ve iktidar kurma tarzı olmasıdır. Bkz. Murat Güzel, "Estetik Aklın Oluşumu: Yücenin Temsili Sorunu ve Siyasalın Eklemlenişi”, Tezkire, 2001, sy. 21, s. 27-36. 
edilmelidir. Benzer biçimde, taklit de tasvir karşılığında kullanılırken kastedilen representation olabilmektedir.

Burada temsil kelimesini öncelikle fiili içeriğinden -örneklemek- ayırarak misal anlamında ele alacağız ve modern zamanlarda tartış1lan representation anlamını neden kazandığına da dikkat çekmeye çalışacağız. Temsil kelimesi, kökeninde "benzer oluşturmak" ile ilgilidir, bu yüzden onu anlatabilmek için bir benzetmeye "ayna benzetmesine" başvurmak öğreticidir. Aynanın karşısında duran bir "asıl" vardır ve aynada hem aslın aynaya kendi yönelişi ve açıklığ 1 -zira örneğin bu asıl, bir insansa, her yanını kapatan bir örtüyle aynanın önünde duruyor olabilir- hem de aynanın imkânları ölçüsünde bir görüntü ortaya çıar. Bu görüntüye "temsil eden" anlamında misal diyoruz. Bu misal, bütünüyle asla bağlıdır ve aslı bazı cihetlerden kendinde tekrar eder. "Fiil olarak temsil" ise, "asla tekrar cihetinden temsil edendeki -yani misaldeki- dönüştür, yani temsil eden bir cihet itibariyle asıla kendinde döner"21 denilebilir. Temsil ile asıl arasındaki bağlantıyı ise temsil eden sağlar. Temsilin, asla tekrar cihetinden temsil edendeki dönüşü, temsil edenin bir cihet itibariyle asla kendinde dönmesidir.

Taklitte de temsilde olduğu gibi esas olan asıldır. Bu itibarla taklit ve temsil ile kastedilen aslın taklidi ve aslın temsilidir. Taklit, "taklit edenin, aslı bazı cihetlerden kendisine kuşatması, kendisine giydirmesidir, zenne gibi. Sahne icraatında zenne, kadın kılığına girmiş erkektir. Zenne, icraatı ile kadını taklit eder. Kendisinde tekrar etmek ile kendisine kuşatmak arasındaki fark, icraat vasıtasıyla açığa çıkar. Bu, temsil ile taklit arasındaki farktır. Temsil dönüşe bağlı olması yüzünden asla uymak mecburiyetindedir. Taklit için de temsilin esasını oluşturan tekrar şarttır aksi takdirde taklit yapılamaz. Temsil etmeyen taklit de edemez ancak bu, temsilin ontolojik olarak öncelikli olduğu anlamında düşünülmemelidir. Taklit eden, temsil cihetinden asla uyar ve taklit edenin ise as1 cihetinden temsile tabi fiil icra etmesi gerekmez, aksine taklit edenin asıl cihetinden temsile tabi olmayan fiil icra edebilmesi taklidin esasıdır." 22 Ayna örneğine dönecek olursak, aynadaki görüntünün bir aslı taklidinden söz edilemez. Oysa mesela zennenin, rolünü temsil değil taklit etmesi gerekir, zira burada erkek oyuncu, rolünde aslı/ kadını "kendinde tekrar etmez"; aksine onu kuşanır. Bu kuşanma, oyuncunun, oynadığı rolden "farklı biri” olmasını zorunlu kılar.

Taklitteki "kuşanma", asla ait sûreti kuşanma anlamındadır. Bu durumda sûret ile asıl arasında bir aynılık olmayacağı açıktır. O halde asıl ve sûret arasındaki ilişkiyi de nasıl anlayacağımız taklidin zeminini belirleyecektir. Yukarıda ele

21 Yalçın Koç, Anadolu Mayası, Ankara, Cedit Neşriyat, 2011, s.139 vd.

22 Koç, a.g.e. s.140-142. 
aldığımız Budist ve Hristiyan ikonlarına dair açıklamada tasvir, taklidi değil de temsili esas aldığ 1 için asla ait bir sûretin kuşanılmasını değil tasvirin sûretin bir iz veya yansıması olarak ortaya çıktığını kabul eder. Taklit, ancak bu ilk izlerin veya yansımaların kuşanılması anlamında taklittir, bizzat Buda'nın veya İsa'nın taklit edilmesi değildir, o yüzden de sûret ve asıl arasındaki ilişkiye dair bir açılama sunmazlar; ortaya çıkan misalin sûretle ilişkisini açıklarlar.

Temsil ve taklit meselesinin "asıll"la olan ilgisi ise düşünce tarihi açısından, bu asılın bir "aynılık" olarak düşünülüp düşünülemeyeceğine olduğu kadar temsildeki "tekrar" fiilinin ne anlama geldiğine dair sorunun cevaplanmasını gerektirdiği için hayatidir. Zira temsil edenin aynıyı kendinde tekrar etmesi ancak "benzerlik"le açıklanabilir. Meselenin epistemolojiyle ilgisi, bizi klasik metafiziğin en önemli sorunlarıyla karşı karşıya getirir. Nitekim cevher üzerine kurulu Aristotelesçi klasik metafizik, "asıl" olan cevherin duyu, hafiza, muhayyile ve rasyonel yetiyle olan ilişkisini açıklamakla yükümlüdür ve açıklama en nihayetinde psukhénin yetilerinin asılla olan ilişkisini ve bunun temsil ve taklitle olan işleyişini "benzerlik" üzerinden kurar. ${ }^{23}$

Konunun diğer veçhesi olan "tekrar" meselesi de benzerde oluşan tekrarın “aynı'nın aynen tekrarı” mı yoksa “aynı'nın farklı tekrarı” $m 1$ hatta “aynı”yı esas almadan tamamen "fark" üzerinden mi açılanacağına ilişkindir. Sonuncusu doğal olarak her tür temsil ilişkisinin reddi anlamına gelecektir. Tekrarda ortaya çıkan "asla geri dönüş" fiili, temsil edene ait olarak düşünüldügünde bu defa da "aslın" mahiyetine ilişkin belirlemenin ne olacağına dair sorunu beraberinde getirir. Klasik metafizik, aslı, ancak noesis fiili itibariyle yani akılla "tutabileceğimizi” kabul ettiği için, temsil edendeki tekrar, benzerliğin akli zemindeki bir tekrar yani te'vil olduğunu kabul edecektir. Nitekim "geri dönme, asla gitme" anlamında te'vil, hem kelamciların hem de filozofların terminolojisinde, Kur'an'daki benzetmelerin, daha doğrusu benzerlik -müteşâbih- olarak kabul edilen ifadelerin, aklî içeriklerine yani "asıl”ların geri götürülmeleri iddiasıdır. Bu noktada sûfîlerin ve özellikle İbn Arabi’nin açık te’vil karşıtlı̆̆ının sebebini de anlayabiliriz. ${ }^{24}$

23 Immanuel Kant'ın klasik metafizik eleştirisinin temelinde de tam olarak bu benzerliğin ve dolayısıyla da cevher fikrinin eleştirisi yer alır. Kant'la birlikte temsil -Vorstellung- bir aslın temsili değildir. Kant açısından mesele, uzay zamanda temsil/tasvir -Darstellung- edilebilir olanla tasvir edilemez yüce -Erhaben- arasında bir ayrım yapmayla sonuçlanır.

24 Bu konu İbnü'l-Arabî'nin eserlerinde pek çok yerde geçmektedir. Örnek olarak bkz. İbnü'l-Arabî, el-Fütûhâtü'l-Mekkiyye, nşr. Ahmed Şemseddin, Beyrut, Dârü'l-Kitâbi'l-İlmî, 2011,c. 1, s. 296. 
Bu noktada tasvir, temsil ve taklidin teoloji alanındaki "teşbih ve tenzih" tartışmalarıyla ilgisi de belirginleşmiş olur. Tartışmalar daha ziyade dil alanında ve Tanrı hakkında konuşmanın imkânına dairdir. Temsil ve taklide ilişkin bu açıklama takip edildiğinde temsilde benzerlik yani "teşbih" üzerinden taklitte ise hem tenzih hem de teşbih üzerinden bir ilişki kurulabileceğini fark ederiz. Teşbih, tekrara ilişkin ve varlıkla ilgili, tenzih ise durmaya -kesintiye- ve fiile ilişkindir. Zira taklit, benzemezlik üzerinden hareket ederken taklit ettiğini dolaylı yoldan temsil etmiş olmaktadır. Temsil ve taklit arasındaki bu fiilî fark ise "asla" ilişkin bir farktan ileri gelir. Bazı şeylerin doğrudan temsili mümkünken bazı şeyler için bu mümkün değildir. İşte bütün mesele, neyin temsil neyin de taklit edilebileceğine dair bu noktada dügümlenmektedir. Öte yandan representation olarak temsil konusunda sanat-siyaset ilişkisi bağlamında yapılan tartışmalar, temsil edenin asıldan bağımsız olarak düşünüldüğünde yahut asla mevcudiyet üzerinden bir iktidar temin ettiğinde ortaya çıkan sonuçlarını göstermek açısından öğreticidir. ${ }^{25}$

Esasen konu bir açıdan Tanrı'nın her türden temsilini reddeden Yeni-Platoculuğa kadar götürebilir, İslam düşünce tarihinde de Mu’tezile kelâmına ve Fârâbî, İbn Sîna düşüncelerine. Filozofların Aristoteles'in Poetika'sına yaptıkları şerhleri bu nedenle bu yazılardaki Aristotelesçi mimesis -Arapça muhâkat- açıklamaları üzerinden bir "görsel sanat teorisi"ne imkân vermez. Tekrar konuya dönersek temsilin bu boyutunun "put” tartışmaları ile ilgisi de açıkça görülecektir. Nitekim Hristiyan düşünce tarihinde karşılaştığımız Ortadoks veya Katolik ikona savunusu bu sorunla ilgilidir. ${ }^{26}$

İslam düşüncesinde teşbih ve tenzih konusunun esası "tevhid"e ilişkin olarak ortaya çıkar. Tevhid kelimesinin kökeninde "vâhid" kelimesi vardır. "Vâhid", daha çok sayısal anlamda "bir"dir. O yüzden tevhid yani birleme, bir anlamda "âlemin" ve dolayısıyla da "oluş"un açıklanmasıyla -çokluktaki birlikle- alakal1dır. Bu birlik, -daha sonra açıklayacağımız üzere- İbnü'l-Arabî’de ulûhiyet mertebesi de olan isimlerin toplayıcılığına karşılık gelen Hakikat-i Muhammediye/ insan-1 kâmil ile mümkündür. Oysa oluşun açıklanmasında sadece tenzihin esas alınması, oluşta ortaya çıkanın yani âlemin- kelâm ve felsefe açısından- herhangi bir biçimde Tanrı ile olan benzerliğini reddetmek anlamına gelir. Aristotelesçi düşüncede insan-1 kâmil fikrine yer olmadığ 1 için bu düşünceye paralel olarak gelişen İslam felsefesinde "nübüvvet" meselesini açıklamak hayati bir önem taş1-

25 Temsil eleştirisi konusunda modern düşüncede zikredilmesi gereken iki isim, Martin Heidegger ve Jacques Derrida'dır.

Bkz. dipnot 16. 
maktadır. Filozoflar sorunu, sophos değil ama philo-sophosu peygamberle eşitleyerek çözmeye çalışmışlar, akabinde de felsefe dili ve din dili arasında bir ayrıma giderek, din dilinin filozofların bilgilerinin bir tür taklidi olduğunu düşünmüşlerdir. ${ }^{27}$ Burada filozofların Poetika'daki mimesis filini -muhâkât-, tamamen akli benzerlik zemininde çözdüklerini de hatırlayalım. ${ }^{28}$ Sonuç olarak onlar için tasvir meselesi, ontolojik değil epistemolojik ve mantıkla ilgilidir yani temsil edilemez olan "Bir"e ilişkin değil somut varolanlara ve cevhere ilişkindir.

Bu noktada Eflâkî Ahmed Dede'nin rivâyeti kilit konumuna yerleşmektedir. Söz konusu rivâyeti Grek düşüncesi zemininde düşünemeyeceğimiz belirginleşmiştir. Bu nedenle rivâyetin yorumlanabilmesi için İbnü'l-Arabî metinlerini izleyeceğiz. Rivâyeti yukarıda tartıştığımız izleklerle de mukayese edecek şekilde açıklayabilmek için konuyu "varlık ve oluş, insan-ı kâmil, tenzih-teşbih ilişkisi açısından tevhid ve tasvirin sınırları" açısından ele alacağız.

\section{İnsan-ı Kâmil ve Taklit}

"Hak Sübhânehû sayısız esmâ-i hüsnâsı -güzel isimleri- bakımından emr'in tümünü içeren kuşatıcı bir varlıkta isimlerini tek tek görmek ve onun vasıtasıyla kendi sırrının kendine görünmesini istedi. Varlık ile nitelenmiş olması nedeniyle 'kendini görmek istedi' de denilebilir, çünkü bir şeyin kendisini kendisi vasıtasıyla görmesi, ayna gibi başka bir şeyde görmesine benzemez. Aynada kişi kendisini, bakılanın yansıttığ 1 sûrette görür. O yer olmadan ve o kişi ona bakmadan önce, böyle bir sûret ortaya çıkmazd. Bu yüzden Hak subhânehu âlemin bütününü, ruhu olmayan bir beden gibi yaratt1, ${ }^{29}$ âlem cilâsız bir ayna gibi oldu....İlahî emir, âlem aynasının cilâlanmasını gerektirince Âdem bu aynanın cilâsı ve bu sûretin ruhu oldu...Binâenaleyh âlem, onun vücuduyla tamamlandı; böylece âlemde o, mühürün/yüzüğün fassı gibidir ki o -fass-, padişahın hazinelerini kendisiyle mühürlediği nakış, nişandır." "30

Fusûsu'l-Hikem'in “Âdemî Kelime” başlıklı ilk bölümü bu cümlelerle açılmaktadır. Oluşun veya âlemin Hak ile ilişkisi, bu kitap ve Fütuhât-ı Mekkiyye' deki esaslar içinde takip edildiğinde "Ben Gizli bir hazineydim, bilinmek istedim ve bu sebeple âlemi yarattım." kudsî hadisine paralel olacak şekilde Gizli Hazine'nin nefesine -Nefesü'r-Rahmân- bağlı bir şekilde anlatılır. Bu Rah-

27 İslam Felsefesinde filozof ve peygamber ilişkisine dair bkz. Ömer Mahir Alper, İslam Felsefesinde Akıl- Vahiy Felsefe Din İlişkisi, İstanbul, Kitabevi Yayınları, 2008.

28 Zeynep Gemuhluoğlu, a..g.e., s. 130.

29 Buradaki fiil “evcede" dir. İbnü'l-Arabî, "halk, takdir, emr ve îcâd” kelimelerini farklı anlamlarda kullanır.

30 İbnü'l-Arabî, Fusûsu'l-Hikem, s. 48, 49. 
mânî Nefes, yukarıdaki alıntıda bahsedilen aynanın yani âlemin oluşumunu da içerir. Nefesü'r-Rahmân, İbnü'l-Arabî yazılarında “Amâ” olarak adlandırılır ve oluşla ilgili ilk mahaldir. İbnü'l-Arabî'nin bu açıklamadaki temel dayanağ 1 ise "Mahlûkâtı yaratmadan önce Rabbimiz nerede idi?" şeklindeki bir soruya Hz. Peygamber'in, "altında ve üstünde hava bulunmayan bulutta -Amâ'da- idi" cevabidir. ${ }^{31}$

Amâ, bütün sûretleri kabul edip aynı zamanda varlıklara sûretlerini verdiği için hem etken hem de edilgendir ve bu meyanda Platon'un Khôra's1 gibi düşünülemez. ${ }^{32}$ Âlemin bütün sûretlerinin "açıldığı" -zuhûr- mutlak hayal ve berzah olan bu hazret, aynı zamanda Hakikatü'l-Muhammediyye'dir ve özel anlamda insan-1 kâmildir. Tek tek varlıklar -fertler- belirli bir ismin tecellî yeri olmasına karşın Hakikatü'l-Muhammediyye, câmî -toplayıc1, "kendi ferdiyetlerini de koruyacak şekilde bir-araya getiren"- isim olan Allah isminin mazharı olması bakımından tekdir ve zâhir ile bâtını birleştirir. Mutlak toplayıcılık, âlem içerisinde sadece burada söz konusudur. ${ }^{33}$ Bu sebeple, Fusûs'un, "Muhammedî Kelime" fassı, Hakk'ın ferdiyyet yönünü açıklar. ${ }^{34}$. Nitekim Fusûsül-Hikem' in her bir bölümü, insan-1 kâmil’in bir yönüne, bu yönü açıklayan bir peygambere ayrılmıştır. Tam da bu yüzden "insan-1 kâmil"i mesela "insanlık" kavramı olarak anlamak mümkün değildir.

İbnü'l-Arabî, âlemin varlığını, “aynı/aynı değil” olarak dile getirir. Âlem, Hak'tan başka her şey” (mâ sivâ) olduğundan O’ndan ayrıdır ve yine sadece Rahman'ın nefesinde açılan “kelimeler” olduğuna göre O'ndan ayrı değildir. Hakkın sonsuz konuşması ve kelimeleri olan âlem, O’nun Nefesi'yle aynı olduğundan Rahman'ın aynıdır. Başka bir şekilde söylemek gerekirse Hak, her şeyden mutlak münezzeh olduğu için âlem O'ndan başkadır fakat âlemde O'nun isimlerinin tecellisinden başka bir şey bulunmadığı için O'nun gayrı da değildir. Aynılık ve gayrılığın -benzerlik ve benzemezliğin- birlikteliği, Hak ve âlem ilişkisini " $O$ ve O değil" şeklinde ifade etmeyi gerektirir; girişte işaret ettiğimiz hakikat ve perde ilişkisi bu minvalde düşünülmelidir. Yani mutlak hayal ve berzah olarak Amâ, veya Rahmân'ın nefesine ait “oluş", İbnü’l-Arabî’nin dilinde “veya” yerine “ve" ile karşı1ık bulur: "Varlıkla sıfatlanan her şey O'dur ve O değildir ( hiye/lâ hiye)

31 İbnü'l-Arabî, el-Fütûhâtü'l-Mekkiyye, c.3, s. 396.

32 Platon'un Khora anlayışı varoluştaki edilgen, dişil ilke olarak yorumlanmaktadır. Bkz. Platon, Timaios, çev. Erol Güney - Lütfi Ay, İstanbul, Cumhuriyet Dünya Klasikleri, 2001, s. 31.

33 Hz. Peygamberin "Âdem, henüz su ve toprak arasında iken ben peygamber idim" hadisi ile de Hz. Âdem'e bütün isimler öğretildiği halde Hz. Peygamber'in, "cevâmiu'l-kelim” olarak bu isimlerdeki bütün hakikatin "toplayıcısı" olduğuna işaret edilir.

34 İbnü'l-Arabî, Fusûsu'l-Hikem, s. 63-64, 214 vd; el-Fütûhâtü'l-Mekkiyye, c. 1, s.125, 210. 
âlemin hepsi $\mathrm{O}$ ve $\mathrm{O}$ değildir (hüve/lâ hüve), bir sûrette zuhûr eden Hak $\mathrm{O}$ ve $\mathrm{O}$ değildir (hüve/lâ hüve) sınırlandırılamayan ve sınırlı (mahdûd), görülemeyen ve görünendir." ${ }^{35}$

Bu açıklama, İbnü'l-Arabî'nin varlık, oluş, âlem ve sûret ilişkisi için sık sık müracaat ettiği ayna ve nûr-zulmet örnekleriyle de paraleldir. Bu benzetmeye göre yokluk varlık için ayna gibidir, sûret orada ortaya çıkar. "Âyân-1 sâbite" veya mümkünler bu sûretlerdir, o yüzden de "yok-var" olarak nitelenebilirler. Mümkünler ne mutlak varlık ne de mutlak yokluktur. Nûr-zulmet örneğinde de mümkünler, nûr olan varlık ile zulmet olan yokluk arasındadır; ne nûr ne zulmettir, hem nûr hem zulmettir yani berzahtır. ${ }^{37} \mathrm{O}$ halde oluş, âlem, bezahî anlamda sûrettir ve Hak ile yokluğun aynısıdır ve aynısı değildir.

İbnü'l-Arabî'nin “ve"ye dayanan bu ifadeleri yani nefy ve isbatın birlikte kullanılması, vesilesini Kur'an'dan almaktadır: "Attığın zaman sen atmadın, fakat Allah attı" ayetine bu hususta çokça müracaat edilir. Ayette "atma" eyleminin Hz. Peygamber'e nisbeti hem doğrulanmıştır -attığın zaman- hem de reddedilmiştir -sen atmadın- ${ }^{38}$ Yine Kur'an'da tenzih ve teşbihin birlikte geçmesi, mesela "O'nun benzeri gibi hiçbir şey yoktur. O, işiten ve görendir" ayetine bu bağlamda dikkat çekilir. ${ }^{39} \mathrm{Bu}$ tür ifadeler, oluşun ve dilin berzah ve mutlak hayalle iç-içeliği ile de ilgilidir.

Temsil ve taklit ilişkisi açısından meseleye bakarsak Fusûs'un baş tarafındaki ayna benzetmesini tekrar hatırlamamız gerekmektedir; âlem Hak'kın karşısında bir aynadır ve aynanın sırrı da insan-1 kâmildir. Âlemin aynada Hak'kın sûreti olarak görünmesini, bir anlamda "temsili" mümkün kılan sırdır insan-1 kâmil. Ancak bu, Hristiyan teolojisindeki Hz. İsa'ya ilişkin kabulden farklıdır. İnsan-1 kâmil, aynanın sırrı olduğu için halk yani âlem tarafından ayna olduğunda da halkın sûretini verir. Bu yüzden insan-1 kâmil, bütün hakikatleri en yetkin tarzda içeren bu âlemin bir "nüsha"sı ve "toplam"1 olarak Allah'1n "kendi sûreti üzerine yarattığını" bildirdiği kişidir. O yüzden de halifedir. İnsan-1 kâmil, ilk hazrete tekabül edecek şekilde Hz Muhammed'dir. Diğer peygamberler ve peygamberlerin vârisleri olan veliler, bu anlamda halife ve "sûret üzere"dirler. En yetkin ayna, her zaman Hz. Muhammed' in aynasıdır. ${ }^{40}$ Ancak bu yazının başında yer alan be-

35 İbnü'l-Arabî, el-Fütûhâtü'l-Mekkiyye, c. 4, s. 12; c. 3, s. 465-466, c.5, s.405.

36 İbnü'l-Arabî, el-Fütûhâtü'l-Mekkiyye c. 1, s. 249.

37 İbnü'l-Arabî, el-Fütûhâtü'l-Mekkiyye c.5, 68-69.

38 Enfâl/17, İbnü'l-Arabî, el-Fütûhâtü'l-Mekkiyye c. 4, s. 12, 85.

39 Şûrâ/11, İbnü'l-Arabî, el-Fütûhâtü'l-Mekkiyye, c. 3, s. 437; c. 4, s. 288.

40 İbnü'l-Arabî, el-Fütûhâtü'l-Mekkiyye c. 5, s. 370-372. 
yitte ve alıntıladığımız rivayette de vurgulandığı gibi insan-ı kâmil Hakkın nişânı olduğu için "bî-nişân"dır. Tam da bu yüzden o bir temsil değildir, ayrıca O’nun herhangi bir şekilde -sözel veya görsel- "temsil" edilmesi de mümkün değildir; ancak "taklit edilebilir."

Âlem, Hak'kın benzeri olarak ancak bu aynada yani berzâhî olarak temâşâ edilebilir. Berzah, hem ayıran hem de birleştiren bir sınır olarak hatta tam da sınır olduğu için âlemin Hakla olan ilişkisini açıklar. Aynanın sırrı, bir temsil ilişkisinde asla rücu eden değil, temsil edenin kendisinde durduğu sınırdır. O yüzden diğer tüm varlıklar kendilerini bu sırda ve aynada görebilirler. Aynanın temsili olmaz, ayna ile temsil olunabilir. O halde mü'min, ancak Hz. Muhammed'in ve insan-1 kâmilin aynasında kendini görebilir, o yüzden de onu "taklid" eder.

Fusûs'tan yaptığımız alıntıda insan-1 kâmilin Hak'kın sûreti olması, onun padişahın hazinelerine vurduğu mühür gibi olduğunu gösterir. Yani âlemdeki bütün "varlıklar" insan-1 kâmil ile mühürlenmiş, işaretlenmiştir. Âlemdeki "benzerlik"in kaynağı bu işarette aranmalıdır. Açıklama, İbnü'l- Arabî’nin "her varlıkta bulunan Hak'kın özel yüzü/yönü” olarak açıkladığg “vech-i has" tabiri ile de ilgilidir. Bu tabirin taklitle olan ilişkisine daha sonra değineceğiz.

İbnü'l- Arabî’nin sûret anlayışı onun yukarıda işaret ettiğimiz mutlak hayal/ berzah açıklamasıyla birlikte düşünülmelidir. Aksi takdirde genel kabulde olduğu gibi Aristotelesçi eidos'a indirgenmesi söz konusu olabilmektedir. ${ }^{41}$ Oysa İbnü’lArabî’nin Aristoteles’teki gibi to de ti olarak tekil varlıktan yola çıktığını iddia etmek mümkün değildir. Hazretin mevcutlar söz konusu olduğunda da sûretten söz etmesi -ki sûret kelimesini mevcutlar söz konusu olduğunda tamlama olarak kullanır- durumu değiştirmez. Sûret, iki temelde yani "Hak'kın sûreti-es-Sûret-“ ve "âlemin sûreti" olarak ele alınmalıdır. ${ }^{42}$ Hak'kın sûreti, âlemin sûretinin de açıldığı mutlak hayal ve berzah olarak Rahmân'ın Nefesi'dir.

Bu noktada İbnü’l-Arabî’nin “olumlu” anlamda kullandığg "taklit”in “mimesis"ten farklı olduğuna dikkat çekmemiz gerekmektedir. Burada taklit, müridin kendisini ve âlemi Hz Muhammed'in ve İnsan-1 kâmilin aynasında görmesi anla-

41 Bkz. Suad el-Hakim, İbnü'l-Arabî Sözlüğü, çev. Ekrem Demirli, Kabalcı Yayınları 2005, s. 572.

42 Sûret kelimesinin Farsça ve Türkçe'deki kullanımlarında, Arapça'da "belirlilik" bildiren "el” takısı olmadığı için kelimenin anlaşılması ancak tamlamalara bağlı olmakta, bu durum da kelime etrafında oluşan anlam karışıklığını artırmaktadır. Burada dikkat edilmesi gereken nokta, sûret kelimesinin âlem için kullanıldığında da sadece tekil varlıkların temsiline işaret etmediğidir. Tekil varlıklar veya olayların tasvirinde daha çok "şekil" ve "nakış" kelimeleri kullanılmıştır. 
mındadır. Bu görmede, mürid nâkıs, ayna kâmil olduğu için müridin görebileceği ayna değil ancak kendi nefsidir. Yazının başındaki rivâyette olduğu gibi, yapılan her tasvirde Hz Mevlana'nın şeklinin değişmesi de bununla ilgilidir. Yine de taklit fiilinde mimesisin teorik açıklamasına benzer bir şey vardır. Kelime kökeninde -kılde- "kurbanların boynuna işaret asmak", "bir kolye vb. takmak" anlamı olan taklid, bir şeyin veya kişinin kendini bir nişanla işaretlemesi, başka bir deyişle bir "sûreti kuşanması" anlamına gelir. Kişi o nişanı kuşanarak kendini taşıdığ 1 nişan açısından bir "ara” veya "berzah" kılar. Mü’minin Hz. Peygamber'i ya da müridin mürşidi taklit etmesi, kendi varlığını bir aslın sûretini kuşanmak sûretiyle $\mathrm{O}$ asla ait ve bağlı kılmaktır. Kişi bu işaretle aslın aynı olmadığını ama O'ndan fark1 da olmadığını ilan eder. Konuyu tasvir açısından düşünürsek, aslolan tasvirde ortaya çıkan temsil değil, tasviri tapılanın taklididir, denilebilir.

Temsil ve taklit açısından konuşurken Efendimizle ilgili önemli bir ayrıma daha dikkat etmemiz gerekir. Hadis-i şeriflerde açıkça ifade edildiği ve yine bütün sûfî gelenekte bilindiği gibi Hz. Muhammed'in rüyada görülmesinde özel bir farklılık esastır. Buna göre rüyada görülen mutlaka O'dur. Başka herhangi bir sûret, O'nun yerine geçemez. ${ }^{43} \mathrm{Bu}$ nedenle rüyadaki sûret, duyusal âlemdeki bir "şeklî" benzerlikle de karşılanamaz. Oysa kişi rüyasında Rabbini gördügünde bile gördüğü Rabbi olmayabilir. Çünkü Hak, âlemdeki bütün sûretlerde tecelli eder ve tecellide tekrar yoktur. Bu rüyalar ise, ehli tarafından "tâbir edilir". Burada "tâbir" kelimesinin kökenindeki "bir taraftan diğer taraf geçmek" anlamı önem kazanmaktadır. Tâbir, sûretin berzâhî doğasıyla ilgilidir ve şekilden mânâya, mânâdan da şekle geçmeyi ifade eder. Bu geçişin imkânı bizzat aynanın kendisi, sırrı olduğuna göre aynanın "sabit" olması anlaşılabilir; ayna, temsili mümkün kılar ama aynanın temsili olmaz.

İbnü'l- Arabî'nin taklidi olumlu olarak ele alması, Fütûhât-1 Mekkiyye'deki miraç anlatısının merkezindedir. Miraç konusunun bizzat temsil konusuyla ve “asla dönüşs"le ilgisi açıktır. İbnü'l-Arabî' de miraç, Hz. Muhammed'in miracının yanı sıra Hakikat-i Muhammediyye ve "insan-1 kâmil" düşüncesi ile paraleldir. Sırf kulluğun tahakkuk ettiği kişi olarak insan-1 kâmilin "kemâl"i, varlığın zâhir ve bâtınında tecelli eden "çokluğu" aşmasi/birlemesi -tevhid- anlamındadır. Aşma, kişinin kendi miracını tamamlaması ve neticede ihtiyarî ölümü -ölmeden önce ölmek- tecrübe etmesi olarak anlaşılır. Bu “ölüm”, bir yolculuk olarak insanın bedensel varlığından aslına doğrudur, yani oluştan varlığa. Dolayısıyla insanın miracı, ilahî tecellinin zıddı istikametindedir - zâhirden bâtına- ${ }^{44}$

43 İbnü'l-Arabî, el-Fütûhâtü'l-Mekkiyye c. 7, s. 41.

44 İbnü’l-Arabî'nin miraç anlayışı ile ilgili bkz. Nasr Hâmid Ebû Zeyd, “İbn Arabi`ye Göre Te)- 
Efendimizin ve sûfîlerin miracındaki diğer bir önemli husus, bu yolculuğun tekrar geri dönülmesiyle tamamlanmasıdır -bâtından tekrar zâhire-. Söz konusu dönüş, miracı felsefi düşünceden ve Hristiyanî gelenekten ayıran en önemli farktır ve böylece Grek düşüncesindeki oluştan varlığa dönüş̧e "bedenin aşılması" esasını ve Hristiyan teolojisindeki "düşüş" yahut "aslî günah"a karş1 "kurtuluş" düşüncesini geçersiz k1lar. Bu bağlamda "cennet” aslî değildir, zira Âdem/insan cennette değil "yeryüzünde halifedir", ${ }^{45}$ bu yüzden beden, dünya veya oluş mutlak anlamda olumsuz değildir ancak, bu çift yönlü yolculuktan sonra asıl anlamına, "tabirine" ulaşır.

Fütûhât'taki anlatıda, miraç yolculuğuna çıkan iki kişi tasvir edilir. ${ }^{46}$ Biri kendi akli verilerini esas alan "nazar sahibi” yani filozof iken diğeri peygamberi taklit eden bir "mukallid"dir. Miraç, müşâhede ve yolculuk boyunca kazanılan bilgilerle ilgili hayli ayrıntılı tasvir ve bilgiler içeren bu anlatıda, belli bir noktaya kadar aynı duraklara uğrasalar da nazar sahibi/filozof için gerçekleşen bilgi, mukallidin elde ettiği hakikatin soluk bir gölgesi/temsili olmaktan ileri geçemez. Daha ilginci, mukallid her durakta o durağın esası olan fert ile -Fusûs'ta anlatılan peygamber/insan-1 kâmil anlamında- karşılaşırken filozof, o esasın külli bilgisinin temsiliyle karşılaşır. Zira mukallid, diğerinin sahip olmadığ bir "vech-i hâs" yani Hakk'a dair özel bir yüz ve yöne sahiptir. ${ }^{47}$

Vech-i hâs -özel yüz/yön- İbnü'l- Arabî külliyatında her bir varlığın Hak'la olan irtibatı, hakikati anlamındadır. Burada mukallid taklit eyleminde hem Peygamber'e hem de kendi hakikatine, yüzüne ve yönüne dönük olmak anlamında taklitçidir. Nitekim akılcının miracı bir sınırda ki bu sınır meleklerin -ve elbette "melekelerin"- geçemeyeceği bir sınırda durur ve tamamlanamaz. ${ }^{48}$ Onun geçemediği sınır, ona ancak âlemdeki varlıklar ve nefsinin melekelerinin bu varlıklarla ilişkileri nisbetinde ulaşabileceği sınırı da gösterir. Mukallid ise nefsinin aynasına yani melekelerinin varlığı temsiline değil Hz. Muhammed'in aynasına baktığı için nihayetinde hem nefsini hem de Rabbini bilerek miracını tamamlar.

vil ve Marifet", trc. Semih Ceyhan, Tasavvuf - İlmi ve Akademik Araştırma Dergisi- sayı 26, 2010, s. 253-286.

45 İbnü'l-Arabî, el-Fütûhâtü'l-Mekkiyye c. 1, s. 191.

46 İbnü'l-Arabî, el-Fütûhâtü'l-Mekkiyye c. 3, s. 410-428.

47 İbnü'l-Arabî, el-Fütûhâtü'l-Mekkiyye c. 3, s. 411.

48 Burada İbnü'l-Arabî'nin insanın melekeleri ve bilgi ilişkisine dair yorumları da konuyla ilgilidir. Nitekim O, meseleyi temsil ve taklitle ilişkilendirir ve nazar sahibinin kullandığ fikir melekesinin daima muhayyileyi taklit ettiğini söyler. Yani filozof, muhayyilesini taklit eden fikir gücünün sonuçlarına, temsiline bağlıdır, onlara takılıp kalmıştır. 
Burada tasavvuf irfanında açığa çıkan sonuca dikkat edilmelidir: "İz olarak" bile sûret/imge, bir yokluğu açığa vurduğu için "Mesih" meselesiyle bağlantılıdır. Gitmiş olan ve bir gün gelecek olanın beklenmesi, ertelenmiş bir "kurtuluş" fikrini de beraberinde getirir. Oysa insan-1 kâmil düşüncesi, varisler olan veliler yoluyla "şimdi ve burada-lı̆̆ı" (İbnü'l-vakt) vurgular. İnsan-1 kâmil, imgesiyle değil kendisiyle şimdi ve buradadır. Miracını tamamlama, taklit eylemindeki asla dönüşü ve asıldan tekrar âleme dönüşü, "şimdi ve burada" mümkün kılmıştır.

Buraya kadar yapılan açıklamaları takip edersek âlemin varlığa gelişi yani oluş-kevn-, mutlak hayal olarak bir berzahı gerekli kılmakta ve sûretler burada açılmaktadır -zuhûr-. Ancak bu açılma ne Yeni Platoncu filozoflardaki gibi nedenselliğe bağlı zorunlu bir sudûr ne de Platoncu alethéia da olduğu gibi "açı1madır". Açılma -zuhûr- bir sahnede değil perdede gerçekleşir. Dil veya tasvir olarak perde, sahnenin perdesi değildir ve açılması kadar "virân edilmesi" de esastır. Perde, oluş cihetinden sûretlerin ortaya çıktıkları gibi âlemin sûretlerinin de geri dönebilecekleri asıl olarak başlangıç ve sondur. İsimlerin, el-Hakikatü'lMuhammediyye'nin ve kalbin/gönlün mahallidir. İsimler bu nedenle "açılamaz", onlarda durulur. ${ }^{49}$ Oluşa ilişkin bu açıklama, eserin değil sanatçının esas alınmasını gerektirir, burada eser yani âlem, sanatçının eseri olarak onun ne aynısı ne de gayrısıdır; taklit ve temsilin anlamı bu şekilde anlaşılmalıdır. Temsil olarak âlem, bir asla geri dönüş fiili itibariyle düşünülmeli ancak onu kendinde tekrar cihetinden değil onunla hem benzeşen hem de benzeşmeyen bir ilişkiyle dile getirilmelidir.

\section{Sonuç Yerine: Tasvirin Sınırları}

Bu noktada artık Eflâkî Ahmet Dede'nin rivâyetine geri dönelim. Bu rivâyet, ilk bakışta bize öncelikte tasvire izin verildiğini ancak temsilin bu örnekte imkânsız olduğunu gösterir. "Bu örnekte” diyoruz zira adı geçen nakkaş, Aynü'd-devle, usta bir ressamdır ve daha önce pek çok kişinin tasvirini yapmış olmalıdır. Rivâyet, meselenin taklit boyutuna dair ilk bakışta bize bir şey söylemez. Zira taklit, sanatçının fiilidir, bir benzerlik olarak temsil de buna bağlı olarak ortaya çıkacaktır. O halde tasvirin "izin verilse bile yapılamaması" ne demektir?

Meseleyi açabilmek için yeniden "sûret" konusuna geri dönmek gerekmektedir. Kısaca anlatılması mümkün olmayan bu konuya ancak bazı vecihler itibariyle değineceğiz. İbnü'l-Arabi'nin sûreti açıklarken birçok kez kullandığ

49 İbnü'l-Arabî'de sûret-perde ilişkisine dair ayrıntılı bir açıklama ve yorum için bkz. Mustafa Tahral1, "Vahdet-i Vücûd ve Gölge Varlık", Fusûsu'l-Hikem Tercüme ve Şerhi içinde, hz. Mustafa Tahralı-Selçuk Eraydın, İstanbul, M.Ü.İ.F. Yayınları, 2005, c. 3, s. 9-63. 
ayna benzetmesinde sûret, aynada ortaya çıkandır, bu yüzden de her zaman hayalî-berzahi bir özelliği haizdir. Yani, bir yönü, Şeyhin "şekil" kelimesiyle ifade ettiği gibi duyusal, bir yanı da ruhî veya manevîdir. ${ }^{50}$ İbnü'l-Arabi'nin "sûret" ve "şekil" arasında yaptığı ayrım ve kurduğu ilişki bu konudaki karışıklığ çözmektedir. Ancak bu noktada "şekil"i de "dışarıda var olan" resimsel bir imge olarak anlamamamız gerekir. Şekil, resimsel bir bütünlük oluşturmayan, duyuyla alg1lanan akışa tabi bir çoğulluğun ancak hayalde bir "birlik" yani sûret kazanmasından sonra biçimsel olarak ifadesidir. Ama bu ifade hiçbir zaman tamamen hayâlî olanla birebir örtüşmez. Üstelik bu, filozofların açıklamalarındaki gibi sadece uyku esnasında ve duyularla ilişki kesildiğinde değil, uyanıkken de böyledir. "İnsanın bu âlemde uykuda olduğu"na dair hadis-i şerifin açıklaması da bu durumla ilgilidir. Nitekim İbnü'l-Arabî'nin açıkça ifade ettiği üzere Allah'ın bir sûrette hayâl edilmesi değil, bir şekille ifade edilmesi yasaklanmıştır. "G1 "Görüyormuş gibi ibadet etme"nin yani ihsanın/güzelleştirmenin anlamı bu farkta anlaşılabilir.

Sûrete ilişkin bu esas unutulduğunda kelime günümüzde olduğu gibi çoğu kere "biçim, form" olarak yani "şekil" anlamında kullanılmakta ve karşısına "mânâ" konarak ikisi birbirinden kategorik olarak ayrılmaktadır. Platoncu bir şekilde düşünüldüğünde de Silenus heykeli örneğinde olduğu gibi “mânâ" bir şeyin asl1, "sûret" ise bedeni, kabuğu olarak değersizleștirilmektedir. Oysa Şeyhü'l-Ekber'in yaptığı ayrım buna izin vermez. Zira sûret, berzahî olduğu için şekli de mânâyı da aynı anda içerir. Yukarıda işaret ettiğimiz gibi yine onun kelamcı ve filozofların te'vil yöntemine karşı çıkması da bununla alakalıdır. Kur'an' daki bir kelimenin lafzını başka bir kelimeyle değiştirerek te'vil etmek için sûret ve mana arasında akli bir ayrıma gitmeniz gerekir. Oysa bu mümkün değildir. İbn Arabî’nin çok defa duyusal olanı akli olandan "daha şerefli” olarak açıklamasının da sebebi budur: "..Seni insan bedenindeki duyusal güçler konumuna yerleştirmem nedeniyle kalbinin kırılmaması için dikkatini çektiğim hususu iyi anla. Kalbin kırılır diye endişe etmemin nedeni, sana göre, duyunun değersiz ve aklın şerefli olmasıdır. Ben ise bütün şerefin duyuda bulunup senin onun işini ve değerini bilmediğine dikkatini çektim." ${ }^{52}$

Temsile dair açıklama dikkate alındığında sûret, temsilde -bizim örneğimizde aynada- ortaya çıkan şeydir, sûretin ortaya çıkması için birinin aynaya bakması gerekir, o yüzden de mimetik fiil esastır. Oluş, Hak'kın kendini, ken-

50 İbnü'l-Arabî, el-Fütûhâtü'l-Mekkiyye c. 1, s. 249; c. 7, s. 312.

51 İbnü'l-Arabî, el-Fütûhâtü'l-Mekkiyye c. 1, s.338.

52 İbnü'l-Arabî, el-Fütûhâtü'l-Mekkiyye c. 5, s. 281. 
dine benzeyen-benzemeyen bir sûrette görmesidir. O halde herhangi bir sanat eyleminde sanatçı ve onun fiili esastır, ortaya çıkan sûret olarak eser değil. Eser, ancak sanatçıya dönmesi, ona ait olmaklığı açısından değerlendirilebilir. Nitekim Gizli Hazine'nin açılması olarak yaratma, yani Nefesü'r-Rahmân, İbnü'l-Arabî'de el-Bedî ismiyle dolayısıyla "ibdâ" fiiliyle açıklanır. "Örneksiz/misâlsiz" yaratma olarak ibdâ, ilahi yaratmanın beşeri meydan getirme ile ilişkisi ve farkını da ortaya koyar. İbnü'l Arabî, bunun insandaki istisnasının muhayyile yoluyla yaratma olduğunu da söyler.

Rahmân'ın Nefesi ya da Amâ olarak adlandırılan bu oluş, örneksiz olması itibariyle yaratanın kendisini -aynılığını-ve ve ondan farklılığını bizatihi taşır, mutlak berzah olması bu anlamdadır. ${ }^{54}$ Berzah yani sınır olduğu için hem ben benzeşir hem de benzeşmez. İşte bütün âlem de bu yaratmanın sonrasında ortaya çıkan olarak değil bu yaratmaya tabi olarak onun içinde gerçekleşir, "yaratmanın sürekliliği” bu anlamdadır. O yüzden âlem bitmiş bir şey değil sürekli yeniden yaratılmaktadır -"Külle yevmin hüve fi şe'n" -ve bu yüzden de canlıdır ve Yaratıcısinı tesbih etmektedir.

Gizli Hazine'nin mutlak gaybı, bilinmek istemeyi "kendi” güzel isimleri açısından görmek istemesi, âlemi kendi içinden ve nefes olarak ortaya çıkarması -zuhûru- süreklidir. Burada ortaya çıkan olarak sûret, temsil ilişkisindeki misal yani temsil edendir. Sûret bu yüzden berzahîdir, İbnü'l-Arabi'nin sûreti sadece âlemin varlığ 1 açısından değil genel olarak açıklarken de her zaman aynada ortaya çıkan üzerinden anlatmasının ve sûretin her zaman bir perde olmasının anlamı budur.

İbnü'l- Arabî’nin açıklamasının Aristotelesçi deizmden, Yeni-Platoncu "sudûr"dan ve hatta panteizmden farkı da bu noktadadır. Burada, Aristotelesçi deizm ve Yeni-Platonculuk theos ve kozmos'u biri diğerine bağlı iki "farklı" unsur olarak anlarken -ki Fârâbî ve İbn Sînâ'nın tenzihte ısrarının sebebi budurpanteizm, tümüyle aynı -özdeş- olduklarını düşünür. Oysa tecellî fiili açısından bakıldığında Yaratıcı, eserinin ne içinde ne de dışındadır. Yani Yaratıcı, yaratma devam ettiği sürece ne "özdeşlik" -aynılık- ne de "farklılık"ta -gayrılık- temellendirilemez. ${ }^{55}$ Gizli Hazine, sürekli açılmakta olduğuna ve yaratılış sürekli

53 İbnü'l-Arabî, el-Fütûhâtü'l-Mekkiyye c. 4, s. 76.

54 Berzahla ilgili olarak bkz. İbnü'l-Arabî, el-Fütûhâtü'l-Mekkiyye, c.1. s. 459, c. 2 s 75.

55 Bu konuda ayrıca bkz. Mesnevî-i Şerif Şerhi, c.13. s. 72-73. Buradaki şerhde de ilgili beyitlere istinaden Hz. İsa'nın Allah'ın oğlu olduğunu iddia edenlerle sırf tenzih yolunu tutanlar arasında benzerlik kurulmaktadır zira her iki yol da âlemi Hak'dan bütünüyle "farklı" bir "gayr" olarak düşünmektedir. 
devam ettiğine göre Hak, ancak "o, o değil”, "hem-hem” olarak ifade edilebilir. Meseleye sûret yani temsilde ortaya çıkan -âlem- açısından bakıldığında da durum değişmez. Çünkü sûret de ortaya çıkma esasında olduğu gibi bir berzahtır. O yüzden mânâya ya da şekle indirgenemez ve yine muhayyel bir esasta dile getirilebilir.

$\mathrm{Bu}$ açıklamalar, tarihte ve günümüzde "tasvir yasağı" olarak tartışılan meseleye de açıklık getirebilir. Fıkıh ilmi içinde yasakla ilgili esas alınan hadislerde yasağa konu olanın "insan ve hayvan" sûretleri olduğunu biliyoruz. Yine İbnü'l- Arabî’yi okumaya devam edersek Hazret, konuyla ilgili olarak "bitki ve cemâdât"ın tasvirinin yapılabileceğini çünkü bu ikisinde "sûret ve şeklin bir ve aynı" olduğunu söyler. Oysa insan ve hayvan için durum böyle değildir, insan ve hayvan sûretlerinin "ruhu" bu tasvirlerde yoktur. ${ }^{56}$

Tasvir yasağına konu olan hadislerdeki ifadeler özellikle modern çalışmalarda "ancak cansızların tasvirine izin verildiğini” iddia ederler. ${ }^{57}$ Oysa canl1l1k konusunda yapılacak bir araştırma hem ayetlerde hem de hadis-i şeriflerde sadece bitkilerin değil bütün âlemin canlı olduğunu gösterecektir: Efendimizin dayandığı kütüğün ağlaması, "göklerdeki ve yerdeki her şey Allah’1 tesbih eder," ayeti ve "Ben Uhud dağını severim, o da beni sever" hadis-i şerifi, ilk hatırlanacak örneklerdir. Taşların Efendimiz'e selam vermesi, "sesinin ulaştı$\breve{g} 1$ yerlerdeki kuru ve yaş her şeyin müezzin lehinde tanıklık edeceğine" dair rivayet ve yine, taşın Musa'nın elbisesini alarak kaçması da bu örneklere ilave edilebilir. ${ }^{58}$ İbnü'l- Arabî’nin anlayışı bu rivayetlere paraleldir; onlar cansız değildir sadece insanlar öyle zannetmektedir: "Canlı olmanın şartı hissetmek değildir. Hissetmek ve hisler (duyular), canlılığa ilave durumlardır. 59 "Ressamın ahirette yaptığı tasvire can vermesinin isteneceği”ne ilişkin rivâyet de bununla ilgili görülebilir. Cansız olan tasviri yapılan değil tasvirin kendisidir. Oysa hayalde ortaya çıkan sûret canlıdır. Bu yüzden temsil değil taklit fiilinin esas alınması anlamlı olacaktır.

56 İbnü'l-Arabî, el-Fütûhâtü'l-Mekkiyye c. 7, s.312 İbnü'l-Arabî, kıyamet gününe ilişkin yorumunda ibadet amacı ile tasvir yapmayan musavvirin durumunun diğerlerinden ayrı olduğunu söylemekte ve bu kişiden yaptığı surete can vermesinin istenmeyeceğini belirtmektedir. elFütûhâtü'l-Mekkiyye c.1. s. 466.

57 Bu konuda örnek olarak bkz. Oleg Grabar, İslam Sanatının Oluşumu, çev. Nuray Yavuz, İstanbul, Yap1 Kredi Yayınları, 1998, s. 92.

58 İbnü'l-Arabî, el-Fütûhâtü'l-Mekkiyye c. 4, s. 386.

59 İbnü'l-Arabî, el-Fütûhâtü'l-Mekkiyye c. 6, s.47. 
Yasağa ilişkin konuyla ilgili olarak benzetmenin esaslarına da dikkat çekerek tasvirin sınırları ve sanat fiili açısından bir ayrım yapılabilir: insan- kâmilin sanatı ve insanın sanatı. Teoloji kadar edebiyat alanını da ilgilendiren bu yönüyle temsil ve taklit konusunun bir diğer boyutu, yani benzetmenin nasıl ve hangi şekilde olabileceğine dair ölçü de yine tasavvufa dair metinlerde açıkça belirtilmiştir. Bu noktada ister İbnü'l-Arabi'ye isterse Mevlânâ'ya müracaat edelim cevap açıtır: ancak peygamberler ve veliler misal getirebilir, benzetme yapabilir: "O meseli getirmek o hazretin lâyıkıdır ki o, sırr u cehrin ilminde âyetdir". ${ }^{60}$ Yani ancak kendisi "apaçık âyet olan" misal getirebilir.

Nitekim hem sûfîlerin metinlerinde ve şiirlerindeki benzetmelerin kaynağı da bu şekilde düşünülebilir: "benzetme yapamayan” Kur'an'da ve velilerin sözlerinde yapılan benzetmeleri taklit eder. Bu ilke, "Kur'an okurken ağlayın, ağlayamıyorsanız ağlıyormuş gibi yapın" hadis-i şerifindeki işaretle de paraleldir. "Taklit" kişinin taklit ettiğinden farklılığının -benzemezliğinin- farkında olduğu benzeşme arzusudur. Bu arzu onu “tevhid"e ulaştırır. Ve yine İbnü'l-Arabi'nin sürekli vurguladığı gibi "tevhid" ise ancak tenzih ve teşbihin birleştirmesiyle mümkündür.

Burada bir peygamber ve insan-1 kâmil olarak Hz. İsa'nın, çamurdan bir kuş sûreti yaptığını ve ona üfleyerek canlandırdığını hatırlayabiliriz. Bu durum Hz. İsa'ya özgü velâyetin bir gereğidir, onun "sırrında" kuş sûreti, şekil ve ruhu birleştiren "canlı bir sûret" olabilmişse de bu, tasvir yapan diğer herkesin harcı olamaz. Bu örneği Hz. Musa'nın sihirbazlarla olan karşılaşmasıyla da birlikte düşünebiliriz. Hz. Musa, asasını dış dünyada kendi başına bir varlık olarak tanımladığında kendisine "korkma" denilerek asasını atması söylenmiş, asa bir ejdarha sûretine bürünerek sihirbazların yılanlarını yutmuştur. Sihirbazlar bunun bir göz yanıltması olmadığını anladıklarında iman etmişlerdir. Asanın ejdarha sûretine girmesi, muhayyel olanın sûretlenmede esas olduğunu gösterir.

İnsan-1 kâmil ve diğer insanların sanat fiili açısından yaptığımız ayrım burada i'câz tartışmalarını hatırlamayı gerekli kılar. I'câz tartışmalarına konu olan, Kur'an'ın, "bir benzerinin getirilmesi” hakkındaki meydan okumasıdır. Kelam geleneğinde Kur'an ve diğer metinler kadar Allah ve âlem arasındaki benzemezliğin yani tenzihin meşruiyetini temin eden bu mesele, sûfî gelenekte bambaşka bir anlam kazanır. Konuyu şiir ve Kur'an ilişkisinde açıklayan Şeyh Galib'in söylemi ilginçtir. Ona göre “âciz kalmaya devam ederek Kur'an'ın meydan

60 Mevlânâ Celâddin Rûmî. Mesnevi-i Şerif Şerhi, , c. 4. 2775. Beyit. 
okumasına karşı şiir söylemeyi devam ettirmek", Kur'an i'câzının devamı için gereklidir. ${ }^{61}$ İnsan sanatının anlamı bu yüzden Hak'ka ve Kur'an'a benzemeye çalışmak, ortaya çıkanın benzemezliğinde âciz kalmak ancak bu başkalığı sürekli yeni benzeşme arzusu açısından da devam ettirmektir. Yani mü'min için şiir söylemeye devam etme, sanat yapmaya devam etme bir zorunluluktur. İnsan-1kâmil ve Kur'an'ın "tev'em" yani ikiz olduğuna dair açıklama ${ }^{62}$ da bu ilişkide açıtır. Aynü'd-devle veya biz, her zaman hem Efendimizi hem de Kâmil olanları anlamaya ve tasvir etmeye çalışacağız, her zaman âciz kalacak olsak da bizzat bu aczin itirafi hem tevhidi mümkün kılacak hem de "Güzel Olan"1 seyretmemize imkân verecektir. ${ }^{63}$

Aczin itirafı anlamında "kulluk" açısından i'caz ve güzel'le ilgili olarak "ihsan"ın ilişkisi burada açığa çıkar. İhsan, "görüyormuş gibi” ibadet etmenin bizzat güzelleştirmenin anlamı olarak belirlenmesi demektir. ${ }^{64}$ Şeyh-i Ekber'in ihsan yorumu, buradaki "gibi" edatının hayâle ait olduğunu açıklar. ${ }^{65} \mathrm{O}$ yüzden de hayâl etmek esasında "benzetmek", teşvik edilmiş hatta ihsan buna bağlı hale getirilmiş ancak bu hayâlin duyuda görülecek şekilde tasviri yasaklanmıştır ki zaten bu "mümkün değildir".

Meseleyi yine İbnü'l-Arabî’nin, “Rabbin sadece kendisine ibadet edilmesine hükmetti" ayetine yaptığı yorumu izleyerek de anlayabiliriz. Ona göre şekilci âlimler, ayette geçen "kazâ" kelimesini, "emretti" anlamında yorumlamıştır. Oysa "hükmetti" olarak anlaşılmalıdır. Zira "başkalarına ibadet edenler", eşyaya "sadece Allah'a daha çok yaklaştırsınlar diye ibadet ettiklerini" kabul etmiş, onları vekil atayanın sûretiyle görünen vekillerin konumuna yerleştirmişler ve her sûrete ilahlığı nisbet etmişlerdir. ${ }^{66}$ Tasvir konusunda da benzer şekilde mesele, emir yahut yasak değil "hüküm” olmalıdır. Yani nasıl Allah’tan başkasına ibadet

61 Şeyh Galib, Hüsn ü Aşk, haz. Abdülbâki Gölpınarlı, İstanbul, Türkiye İş Bankası Yayınları, 2006, beyitler: 785-795.

62 İbnü'l-Arabî, el-Fütûhâtü'l-Mekkiyye c 5, s. 137 vd.

63 Nitekim Hz. Mevlânâ, "Ben his gözüyle görülen sûret değilim, belki mürîdlerin bâtınında sözlerimden zuhûr eden zevk ve hoşluğum; O demi bulduğun ve o zevki tattığın vakit ganîmet bil ve şükür et ki işte ben oyum ve beni buldun” buyurmuşlardır. Bkz. Mesnevî-i Şerîf Şerhi, c. 13. s. 43.

64 Şeyhü'l-Ekber'in "ihsan” yorumu, "Cibrîl hadisi” olarak bilinen hadis-i şerifle ilgilidir. Hadiste, "ihsan -güzel/güzel kılma- nedir?” sorusuna Efendimiz, "Allah’1 görüyormuş gibi ibadet etmek" cevabını vermiştir. Hadisin tamamı için bkz. Müslim, İmân 1, 5; Buhârî, İmân 37.

65 İbnü'l-Arabî, el-Fütûhâtü'l-Mekkiyye c. 3, s. 185.

66 İbnü'l-Arabî, el-Fütûhâtü'l-Mekkiyye, c. 5, s. 366. 
etmek "zaten" mümkün değilse esasında muhayyel olan bir şeyi tamamen duyuda temsil edecek şekilde "temsil" etmek de mümkün değildir.

O halde sonuç yerine artık yazının girişindeki Hazreti Niyâzî-i Mısrî’nin ilahisinin ilk beytini birlikte okuyabiliriz:

"Kırıp bin pâre eden şişe-i kalbi celâlindir

Yine her pâresinden görünen rûy-1 cemâlindir."

Celâl, aynayı (temsili) kırar ama her pâreden yine cemâl görünür.” Teşbih ve tenzihin birleştirilmesi yani "tevhid" budur. 


\section{Kaynakça}

Ahmed Eflâki, Ariflerin Menkıbeleri, terc. Tahsin Yazıc1, İstanbul, Remzi Kitabevi, 1986.

Allen, Danielle S., Why Plato Wrote, Blackwell Publishing Ltd., 2013.

Alper, Ömer Mahir, İslam Felsefesinde Akıl-Vahiy Felsefe Din İlişkisi, İstanbul, Kitabevi Yayınları, 2008

Aristoteles, Poetika, çev. Nazile Kalaycı, Ankara, Pharmakon Yayınları, 2012.

Belting, Hans, Floransa ve Bağdat, Doğu'da ve Batı'da Bakışın Tarihi, çev. Zehra Aksu Yılmazer, İstanbul, K.Ü.Y. 2012.

Burckhardt Titus, Doğuda ve Batıda Kutsal Sanat, trc. Tahir Uluç, İstanbul, İnsan Yayınları, 2017.

Coomaraswamy Ananda K., "The Origin of the Buddha Image", The Art Bulletin, vol. 9, no. 4, Jun., 1927.

Dahiyat, Ismail M., Avicenna's Commentary on the Poetics of Aristotle, Leiden, Brill, 1974.

Eflatun, Şölen, çev. Azra Erhat-Selahattin Eyüboğlu, Remzi Kitabevi, 1958.

Gemuhluoğlu, Zeynep, "Metaforların Kognitif İçeriklerinin Felsefe ve Şiir Dili Açısından İncelenmesi, - Fârabi, İbn Sina ve İbn Rüşd Örnekleri-", $M$. $\ddot{U}$. Ilahiyat Fakültesi Dergisi, 34, 2008/1.

Guscin Marc, The Image of Edessa, Leiden-Boston, Brill, 2009.

Güzel, Murat, "Estetik Aklın Oluşumu: Yücenin Temsili Sorunu ve Siyasalın Eklemlenişi”, Tezkire, sayı 21, 2001.

Haşlakoğlu, Oğuz, Platon Düşüncesinde Techné, İstanbul, Sentez Yayınları, 2016.

İbnü'l-Arabî, Fusûsu'l-Hikem, thk. Ebu'l-Alâ Afîfî, Beyrut-Lübnan, Dârü'l-Kitâbü'l-Arabî, 1946. Kitâbi’l-İlmî, 2011. , el-Fütûhâtü'l-Mekkiyye, nşr. Ahmed Şemseddin, Beyrut, Dârü'l-

Kaçar, Turan "İmgenin Transformasyonu: Bizans Dünyasında İkona Tartışmaları”, Eskiyeni, sayı 2, 2008.

Kemal, Salim, The Poetics of Alfarabi and Avicenna, Leiden-New York-Kobenhavn-Köln, Brill, 1991. 
Koç, Yalçın, Anadolu Mayası, Ankara, Cedit Neşriyat, 2011.

Mevlânâ Celâddin Rûmî, Mesnevi-i Şerif Şerhi, trc. ve şerh Ahmed Avni Konuk, haz. Selçuk Eraydın, Mehmet Demirci, Mustafa Tahralı, Sâfi Arpaguş, Necdet Tosun, İstanbul, 2008.

Nasr Hâmid Ebû Zeyd, “İbn Arabi'ye Göre Te'vil ve Marifet”, trc. Semih Ceyhan, Tasavvuf - İlmi ve Akademik Araştırma Dergisi, sayı 26, 2010.

Ricoeur, Paul, Hafiza, Tarih, Unutuş, ter. M. Emin Özcan, İstanbul, Metis Yayınları, 2012.

Stokes, Margaret, The History of Christian Art in the Middle Ages, London, 1891.

Suad el-Hakim, İbnü’l-Arabî Sözlüğü, çev. Ekrem Demirli, İstanbul, Kabalc1 Yayınları 2005.

Şeyh Galib, Hüsn ü Aşk, haz. Abdülbâki Gölpınarlı, İstanbul, Türkiye İş Bankası Yayınları, 2006.

Tahral1, Mustafa, "Vahdet-i Vücûd ve Gölge Varlık", Fusûsu'l-Hikem Tercüme ve Şerhi içinde, haz. Mustafa Tahralı-Selçuk Eraydın, c. 3, İstanbul, M.Ü.İ.F. Yayınlar1, 2005.

Thomas Aquinas, The Summa Theologica, Benziger Bros. edition, translated by Fathers of the English Dominican Province, 1947.

Üçer, Halil İbrahim, İbn Sina Felsefesinde Suret, Cevher ve Varlık, İstanbul, Klasik Yayınları, 2017.

\section{İnternet Kaynakları}

https://ganjoor.net/moulavi/shams/ghazalsh/sh1759/ 